\title{
The Role of Library Director and Users in Planning a Building or Renovation
}

\author{
Jingwu Han* \\ Library \\ Tonghua Normal University \\ Tonghua, China \\ E-mail:*dbcy9999@163.com
}

\begin{abstract}
The librarian plays an important role in the design and construction of a new facility. Frequently, if the organization is large and the project complex, the committee serves to represent entire staff, as well as members of the public, student body, faculty, or other constituents. City or institutional employees including architects and project managers from facilities departments typically work with the committee, bringing their expertise and representing the parent institution. Once construction begins, the project team forms to meet weekly. This team provides ongoing communication and makes potential changes to the site design. Usually a representative from the library, an institutional facilities staff member, a representative from the architectural firm, and the construction project manager meet weekly to discuss the progress of the project.
\end{abstract}

Keywords-Preliminary Planning; Funding for Library Buildings; Site Selection; Steps to a Library Design; Emergency Planning and Safety

\section{INTRODUCTION}

Convincing stakeholders that funding for new or renovated library space is necessary can be a challenge. Here are some suggestions for mounting a campaign for new space. If the library supports a school or college and has outgrown the allotted space, a recent accreditation review may aid the cause. Although there are no longer guidelines for space requirements published by library organizations or accrediting bodies, a visiting committee that per-forms a review of a school or college may notice if the library space has limited seating, if the stacks are full, or if technology seems adequate for the student population. Although these accreditation reviews only occur every 10 years [1], or 5 if the school is weak in some areas, administrators are likely to remedy a poor review before the next visit. In schools and colleges [2], faculty and student senates, individual faculty members, and students may lend their voices to those in the library, asking for an updated facility. All private schools and all colleges and universities have comparator institutions [3]. These comparator schools are determined by looking at all the students who are accepted by the local school and selecting the ones who do not choose to attend the local school, but rather attend another institution. When reviewing that data, schools most students choose to attend are considered the comparators, and a case may be made if all or most of the comparator schools have newer library facilities. Likewise, corporations have competitors [4], and managers of corporate libraries may use better facilities at competing organizations to argue for more space. Most parent organizations develop master plans where they envision future space planning for the institution. These master plans may plan out for 15 or 20 years. This gives the institution (or city) a coherent way to man-age the planning of physical plant space and funding. A wise library manager would volunteer to participate in the master planning process [5]. In cities and towns, public librarians and school librarians may also make the case by showing town leaders and school administrators the new libraries of nearby towns [6]. Sometimes community members cannot envision what an excellent facility could offer until they see for themselves. It is always a good idea to visit newer libraries whenever planning a library. In all instances, no matter what kind of library or information center, the head of the library should have a vision for a new library and find ways to share that vision broadly. Some library managers have gone so far as to have students develop a library design.

\section{PRELIMINARY PLANNING}

One of the most important arguments to convince college or university administrators is to contend that the library needs to better support the mission of the school. What is at the heart of any college or university? The answer is student learning. Scott Bennett6 makes the case that academic library managers who are planning new buildings should utilize learning theory to design user spaces. Too often librarians know more about what does not function (for example heating/air conditioning problems, unwelcoming entrance, limited wiring, and not enough space for technology). Many projects are designed around trying to design a library with all those problems fixed Bennett argues that library managers should begin planning way before any funding is made available and that managers should think about assessment, how the success of the building will be measured before any design is accomplished. Working with faculty and administrators, library managers need to decide how learning can take place in the library and how that learning can be measured. The early stages of this concept were the development of learning commons in schools. Even public libraries and school libraries now offer some type of space for collaborative learning with easy access to technology. 


\section{FUNDING FOR LIBRARY BUILDINGS}

Institutions usually have funds in their operating budget for minor repairs or upgrades. However, when contemplating a major renovation or a new facility, funding must come from a capital budget. Public colleges and universities usually petition their country legislature for capital funds for projects like a library. This money may be supplemented with gifts raised from alumni. Private universities, colleges, and schools use either bonds, gifts, or a combination of the two. Funding for public library construction usually comes from the municipality, and also may be supplemented with revenue from fund raising. In many country, such as USA Massachusetts, there is a program to assist local communities with both planning and construction [7]. Funding for new public school construction that will include a school library with the other classrooms is a part of school district funding. Special libraries rely on their organizations for funding library renovations.

\section{Site SELECTION}

The location for the library project may be obvious, especially if it is an expansion to an existing building. However, if a totally new facility is planned, a new location may be needed. The importance of choosing a site creates the potential for political behavior. Someone may have a parcel to sell or a neigh-bor may not want a facility in his neighborhood. In the case of school libraries, site choices are not made by a library building committee, because the library will be part of an entirely new building. In academic libraries and special libraries, multiple groups may be vying for one site. For public libraries to stay above potential disputes, the building committee needs to develop site selection criteria before looking at any possibilities.

Many factors need consideration:

- Availability of the site

- Cost of the land

- Accessibility of the site

- Adjacent users and services

- Orientation of the site

- Zoning of the site

- Topography of the site

- Shape of the site

- Availability of parking and/or public transportation

- Hidden obstacles and subsurface conditions of the site.

The committee also may want to add local criteria such as location near schools, downtown shopping, or other requirements. The committee should rank these criteria, giving extra points to criteria that are priorities. The next step is to actually look at the sites and to assemble drawings or tax maps if possible. Each site is evaluated using a spreadsheet based on objective criteria. The sites with the highest scores will undergo further investigation and scrutiny until a choice is determined.

\section{STEPS TO A LiBRARY DESIGN}

After a site is selected and a budget developed for the project, the design of the library comes next. The first task is to develop an architectural program, which is a document that describes in words and assigns the amount of space in square feet for every room and space. The architect will take this program and use it to design the spaces. Because this is the guide that architects will use, it is very important to think through each space and to get the details right before any drawings are made. If someone wants to make a change later in the process, the costs may be prohibitively high. Often librarians choose a specialist to develop an architectural program. The person writing the program will develop a template or form for each room or library area that includes:

- name of area

- purpose of area

- number of occupants (staff and users)

- size measured in square meter

- description of equipment, furniture, book collections, etc.

- a listing of architectural requirements such as location, adjacency (direct, close, and negative), acoustical sensitivity, security issues, special lighting needs, special electrical, data and communication, plumbing, special heating, ventilating and air conditioning (HVAC), and other comments. Adjacencies help architects understand where services and collections should be located. A circulation desk should be located near the front door (direct adjacency), information commons should be located near group study rooms (close adjacency), and the children' $\mathrm{s}$ room should be located away from quiet study areas (negative adjacency).

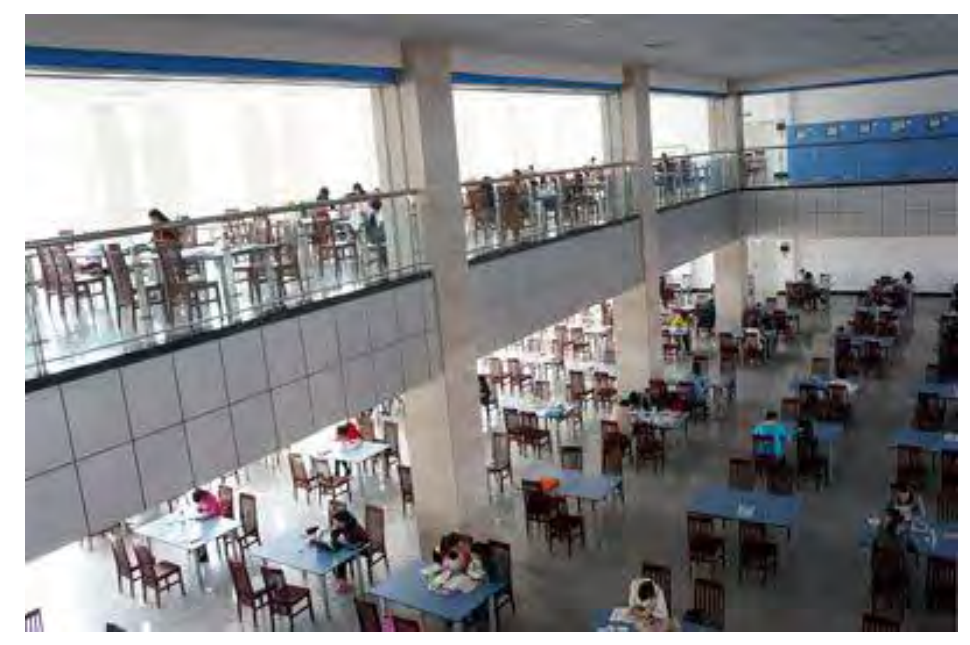

Fig. 1. Student Station 


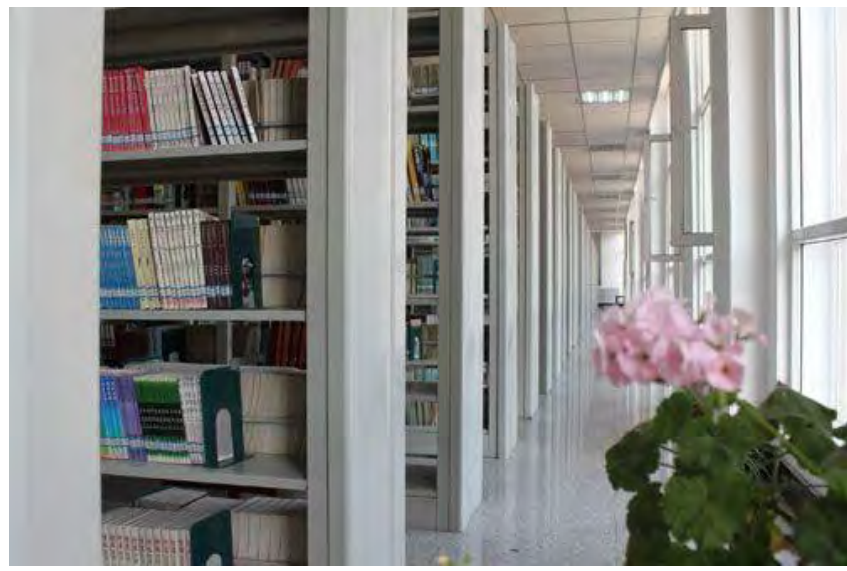

Fig. 2. Book Trunk Space

TABLE I SAMPLE PAGE FROM LIBRARY ARCHITECTURAL PROGRAM

(Library of Tonghua Normal University) Inter library Loan (Library of Tonghua Normal University)

\begin{tabular}{|c|c|c|}
\hline \multicolumn{3}{|c|}{ Inter library Loan (Library of Tonghua Normal University) } \\
\hline Paper Book & Quantity & Square Meter \\
\hline Electronic Book & 1240000 & \\
\hline Computer & 940000 & \\
\hline Staff & 300 & 400 \\
\hline Student Station & 40 & $\mathbf{2 5 0 0}$ \\
\hline Book Trunk Space & $\mathbf{2 5 0 0}$ & $\mathbf{1 0 0 0 0}$ \\
\hline Photocopy Machine & $\mathbf{2 6 0 0}$ & $\mathbf{4 0 0}$ \\
\hline Scanner & $\mathbf{3}$ & 400 \\
\hline Shelving & 132 & 4900 \\
\hline Cabinet for Supplies & 1500 & 18600 \\
\hline Public Area & & \\
\hline Subtotal & & \\
\hline
\end{tabular}

The completed architectural program confirms the size and functionality of spaces that will be designed. This program may need to be revised to work within a set budget. A comparison sheet drawn up showing each program area as it exists currently, as described in the program and in a comparable library, will help decision makers.

Selecting an architect and other design professionals may be done in a number of ways. The institution may have a preferred architect, or the facilities department may put out a request for information (RFI) to solicit a number of architects who might be interested. They will review the RFI and probably interview a small number of architects. Members of the selection committee should visit any libraries designed by the architect candidates and be suspicious of architectural firms that have not designed a library in the past. There are cases where the first library of an architectural firm is excellent, but there are also cases where problems unique to libraries are not considered by architects who have no experience with libraries; lighting and storage issues can often be poorly designed. The role of the architect is to work with the building committee, using the program as a guide. The architects work in three stages, each with more detail as the design becomes more complete. The first is schematic design, where a basic layout of the rooms and spaces is developed.
There will be a lot of back and forth, no matter how complete the program. Once the basic idea of where all the doors and spaces will be located, the architects seek acceptance of the schematic design and move on to the design development phase, where more detail is added. Actual furniture, stacks, and equipment are shown on the drawings. The final phase of design is developing the construction documents. These are the multilayered drawings that a builder will use first to bid for the job and then to actually construct the library. There is a sheet for lighting, for plumbing, for telecom, etc. All the builtin cabinets and shelving is specified and shown in detail. Construction estimates should be made by the architects at the end of each phase so that everyone is comfortable that the building will be built within budget. If these estimates are too high, and this happens often, then the architect may need to work with the committee to find ways to make the building smaller, or adjust expensive finishes or make other changes to save money. This process is termed "value engineering." Sometimes a value engineering firm is hired to look at design plans, work with the architects, and find ways to save money. Another area of this process is interior design, where someone chooses colors, furniture, fabrics, window treatments, and light fixtures to complete the project. Working with a design professional will result in better, more durable products. Lighting in libraries is particularly challenging and should be set up with flexibility in mind. During the lifetime of the building, furniture and even stacks will be moved; the ceiling lights should still provide adequate illumination.

\section{EMERGENCY PLANNING AND SAFETY}

Every library or information center should have an emergency plan. These plans and related emergency training of library staff help everyone involved know what to do when emergencies occur, for example, where to go during a fire (or drill) so that everyone in a unit is accounted for. Every library should have (and update) a basic checklist that lists specific situations and what an employee should do in each case. Many libraries have an emergency planning committee that keeps the plan up to date and oversees training and drills. This committee also works to designate employees who are responsible for clearing the building. Committee members represent all aspects of the library and often other emergency workers, such as people who work in fire and police departments. These officials are happy to offer a review of the facility for any out of date emergency equipment and to help with staff training, including fire drills etc. Because most libraries offer hours of service beyond nine to five, Monday through Friday, usually with fewer managers available, training evening and weekend employees is especially important. 


\section{PART OF EMERGENCY PLANNING IS TO STOCK SUPPLIES INCLUDING}

Simple things like sheets of plastic to protect materials from leaks, fans, a telephone tree to contact people in the organization, and phone numbers for contractors who will come during an emergency. Some libraries package emergency kits throughout the departments in the library. Practical articles, such as flashlights, batteries, gloves, note pads, and pen may be included in the kits.14 Fire, floods, water leaks, natural disasters, medical and security emergencies happen, and library and information center employees need to be prepared. No matter how detailed and up to date, a policy is only good if the employees in the library or information center have had recent emergency training.

A great resource for emergency planning is the Northeast Document Conservation Center' s Web site. This nonprofit organization offers an online template for any cultural institution to use to develop an emergency plan. Using the template on their Web site makes it easier for an organization to make sure that someone has planned and pulled together all the relevant information. Establishing a safe and secure workplace for staff is a joint responsibility. Managers can work hard to ensure a good environment, but staff members also need to cooperate and participate. For example, repetitive motion injuries can be a problem for library staff, especially those who do not have to move from their desks for long periods. A manager can ensure that a work site analy sis is conducted and training provided, but the employee needs to pay attention to posture and other suggestions to avoid injury. Also, employees need to understand their roles during an emergency and to carry out these roles in the plan. Overall one never knows when or if an emergency will strike. Careful planning helps make sure that any emergency will be well managed: people will know what to do and where to go, and everyone will be kept safe during an emergency.

\section{LIBRARY MAINTENANCE}

In most libraries, the people who clean and perform small repairs are not employed by the library, but rather work for another unit in the parent institution or are hired by an external company. Although most people want to do a good job, sometimes working with facilities personnel can be frustrating because they do not always communicate about what they are doing and when the work will be performed. The key to success, when working with housekeeping and maintenance personnel, is to treat them like library or information center employees, communicate with them, and invite them to library or information center events. In a larger organization, it is a good idea to delegate someone to serve as the primary liaison to facilities and maintenance personnel. In a small library, this work usually falls to the director. This liaison should have good people skills and will need to learn about cleaning, repairs, and facilities maintenance. Often the facilities staff will be willing to educate the liaison in the workings of their trades. This person does not need to know how to repair a toilet or service air conditioning, but should have some knowledge about what regular service these items need and should know how to watch for signs if something is not working properly. They also need to be good at follow-up and tracking many details. Some libraries develop service plan agreements with facilities and maintenance departments. This agreement defines the nature of the work done by cleaning personnel, for example, how often wastebaskets will be emptied in restrooms or how often vacuuming will be performed. Once representatives from the two organizations sign this agreement, then the level of service can easily be monitored and any divergence from the agreement pointed out Sometimes job descriptions for housekeeping staff are developed, especially if these employees work directly for the library. Sample housekeeping contracts and job descriptions are available.16It is always a good idea for the facilities liaison to walk through the library every day and note any issues. Graffiti, for example, tends to expand once it begins unchecked. This staff person will learn the appropriate way to log concerns about maintenance and how best to follow up if work is not completed in a reasonable time.

\section{CONCLUSION}

Library and information center physical plants are complex, open more hours, have heavy use, and require an engaged manager to communicate the physical needs of the users and staff. Successful managers learn the language of facilities and communicate well with other organizational personnel. After a long planning, design, and building process, the hard work is repaid by the opportunity to work in a successful, welldesigned facility.

\section{ACKNOWLEDGMENT}

This research was financially supported by Research Foundation of Education Bureau of Jilin Province (Grant No.2016238 and Grant No.JJKH20180860KJ) and by the Project of Education Department of Jilin Province College students venture project (Grant No.201708301E).

\section{REFERENCES}

[1] Baltimore County Public Library, Strategic Plan IX: Making a Difference 2013-2015, 2016, http://www.bcpl.info/about-us/adminis tration\#strategic-plan.

[2] Deanna Marcum, Library Leadership for the Digital Age, Information Services \& Use 36, no. 1-2, 2016, pp. 105-111.

[3] Sherri Brown, Charlie Bennett, Bruce Henson, and Alison Valk. NextGen Learning Spaces. Spec Kit 342, (Washington, DC: Association of Research Libraries, 2014, 12.

[4] Joyce Sternheim, I Have to Change to Stay the Same, New Library World 117, no. 1, 2016, pp.22-34.

[5] Jennifer Velásquez, Lessons Learned from a New Teen Space, Young Adult Library Services 15, no. 1, 2016, pp. 31-33.

[6] Michelle Twait, If They Build It, They Will Come; A Student-Designed Library, C\&RL News 70, 2009, pp.21-24.

[7] Scott Bennett, Putting Learning into Library Planning, portal: Libraries and the Academy, 15, no. 2, 2015, pp.215-231. 